\title{
An Analysis of Consumer Behaviors in Choosing Public Transportation
}

\author{
${ }^{* 1}$ Nurhasan, Hadhori, ${ }^{2}$ Putro, Utomo Sarjono \\ ${ }^{*}$ Student, designation, School of Busniess and Management Institut Teknologi Bandung, Jl. Ganesha no.10 40132, \\ Bandung, Indonesia \\ ${ }^{2}$ Lecture, designation, School of Busniess and Management Institut Teknologi Bandung, Jl. Ganesha no.10 40132, \\ Bandung, Indonesia
}

Note: * Indicates corresponding author

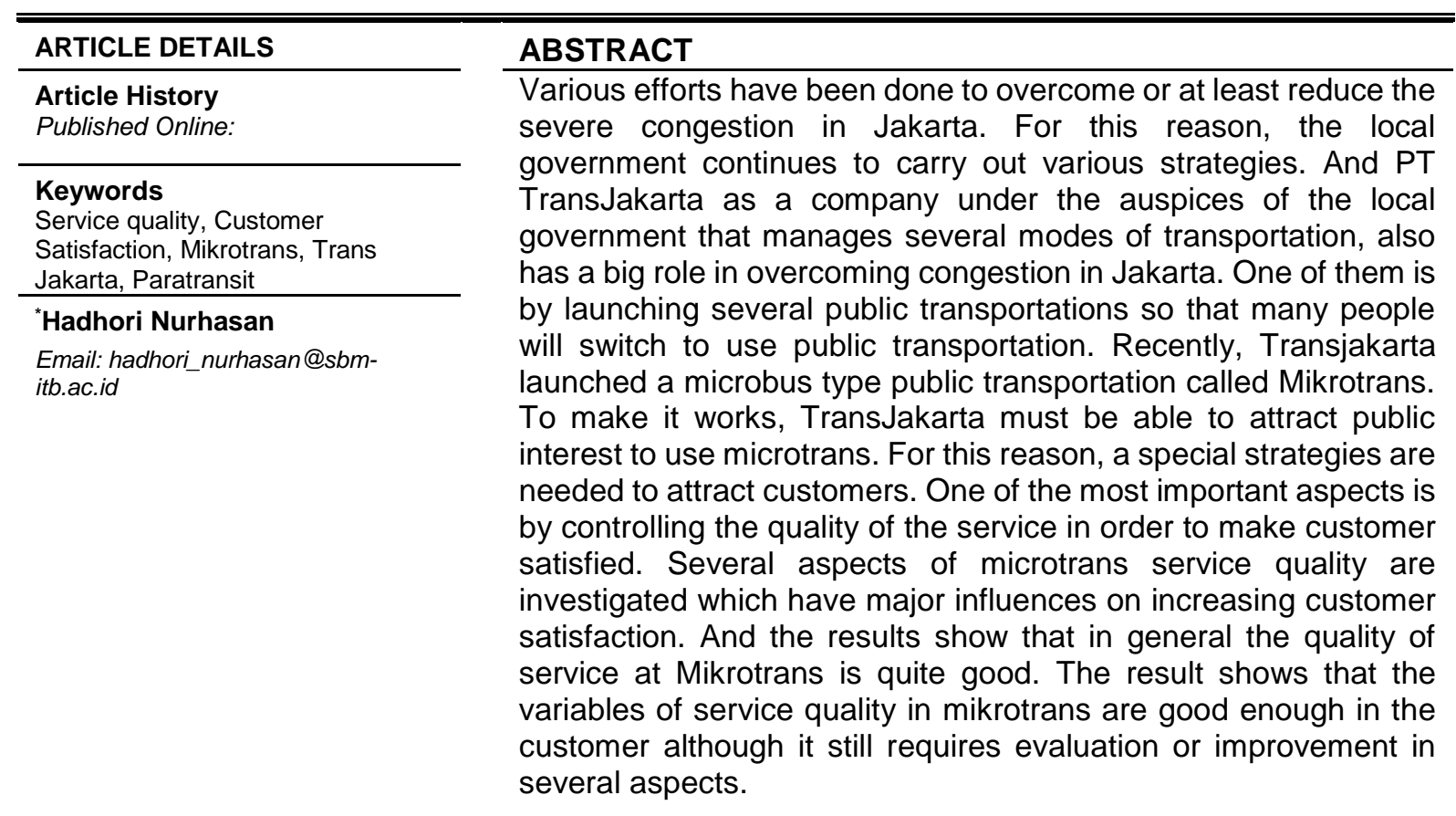

\section{INTRODUCTION}

Mikrotrans is a kind of microbus which has been acquired by PT TransJakarta. Microbus which is called mikrolet in Indonesia is one type of public transportation that is very often found because it is useful for accommodating many passengers. Microbus is certainly designed with the aim to make it easier for people who do not have private vehicles when they want to travel for certain routes. In addition, people in several cities, especially with severe congestion levels like Jakarta, are also encouraged to use public transportation more than private vehicles to avoid congestion. But unfortunately, most microbuses in Indonesia including in Jakarta get a lot of negative images from the public. This is due to several attitudes that are often done by microbus drivers and the designs as well as facilities available in the microbus. One more thing that is also a problem is microbus which is expected to reduce congestion, in fact, they often cause congestion. This is due to the attitude of microbus drivers, such as often stopping carelessly and frequently stopping for a long time to wait for the passengers because the number of passengers carried must also meet the target.

Besides that, the carelessness of microbus drivers often makes passengers feel uncomfortable. Therefore, this became a challenge for PT Transportasi Jakarta or better known as TransJakarta that has made a breakthrough by launching Mikrotrans with a system that may not be commonly applied to 
conventional microbus. Mikrotrans is expected to be one of the alternatives for public transportation to reduce the use of conventional microbus which have a negative image to the public. With this breakthrough, it is expected that the Jakarta citizens will have a positive image of mikrotrans.

From the exterior design Mikrotrans may look the same with other microbus in general. However, there are several differences in mikrotrans that are not owned by most other microbuses. One of the most obvious differences is the driver never stops for a long time to wait for passengers and the payment system uses e-money card and zero rupiah, because they are already paid with a fixed salaries by the Jakarta government regardless the number of passengers they get and they do not collect fares from passengers anymore. Because of that, mikrotrans drivers are prohibited to stop for a long time just to find passengers. Another difference is that the mikrotrans are not allowed to stop at any place, unless at certain places that have become the halts for mikrotrans. In addition, the driving style of the driver is controlled by the local government so that they do not drive recklessly and they will receive a warning from the local government if they do so.

Some Mikrotrans also have air conditioning inside. In addition, the quality of vehicles that are used by mikrotrans is generally better than most conventional microbuses. This is because the Mikrotrans public transportation is expected to make passengers who ride it feel comfortable. TransJakarta really pays attention to the factors that can make mikrotrans passengers feel comfortable, starting from the comfortable design of the vehicle, the provision of air conditioner (even though it is only available in some vehicles and not all), and the behavior of the driver is controlled.

With such condition, mikrotrans as one of several types vehicles launched by PT TransJakarta is also expected to play a role in reducing congestion in Jakarta. But in reality, mikrotrans cannot easily reduce congestion in Jakarta. This is caused by several factors, one of them is mikrotrans is not yet widely known and interested Jakarta citizens. Although TransJakarta has tried to provide the best possible facilities and services for microtrans vehicles, however it cannot automatically make many Jakarta citizens choose Mikrotrans and feel satisfied with Mikrotrans services. To fill this gap, it is very necessary to find out why the passengers are still unsatisfied and why mikrotrans are still unpopular to Jakarta citizens.

Thus, the results of this research are expected to contribute in helping TranJakarta make strategies which are needed to make more Jakarta people choose mikrotrans and feel satisfied with mikrotrans services, so that mikrotrans can play a maximum role in reducing congestion in Jakarta.

If mikrotrans could provide the best possible service and make the passengers who have used it feel satisfied and have a good impression of mikrotrans, the people who have used Mikrotrans will be very likely to invite the others and give positive testimonies. Therefore it is very important for TransJakarta to know how the public's assessment of the services provided by mikrotrans as an input for TransJakarta to make certain strategies that will give a positive impact on the public image of mikrotrans services by making new positive strategies and changing or removing present policies that can give a negative impact. It is also very important for TransJakarta to know what factors are considered by people in choosing public transportation and what factors can make them satisfied. So, the background of this research is to analyze the factors that influence people in choosing the type of transportation, as well as to explore the variables on Mikrotrans that affect passenger satisfaction. So the expected output of this research is the variables that can be used as a consideration to enable TransJakarta in improving the service quality of Mikrotrans so that the satisfaction level of mikrotrans passengers will continue to increase. If the satisfaction level of mikrotrans passengers continues to increase, this can encourage Mikrotrans passengers to recommend people who have never used Mikrotrans especially those who do not have private vehicles and often use public transportation other than microtrans to use it, so that the number of mikrotrans passengers is expected to increase. Thus, the maximum role of microtrans to reduce congestion in Jakarta will also be achieved.

Besides that, mikrotrans also have to compete with various types of public transportation such as taxis and ojek which are already using online systems such as Gojek and Grab. Therefore, this journal will try to analyze consumer behavior in choosing public transportation, hoping that their preferences will be identified when choosing public transportation. From there it is also expected to understand which variables need to be improved to make customers more satisfied, 
as well as which variables are considered good to maintain.

In the long term TransJakarta also has a mission in the future to integrate all microbuses with the Jak Lingko system like mikrotrans. However, this still faces obstacles. One of the obstacles is that not all microbus drivers want their microbus to be integrated with the Jak Lingko system, because some drivers still prefer to get daily income from conventional microbus, especially those who usually get high daily income. Therefore, at least TransJakarta can maximize the functions of existing Mikrotrans fleets so that every fleet gets the maximum number of passengers.

\section{LITERATURE REVIEWS}

In several literature reviews before likes from Sharma, D., Pandit, D., \& Bose, T. (2020) and Behrens, R., McCormick, D., Orero, R., \& Ommeh, M. (2017) or Noor, H. M., Nasrudin, N., \& Foo, J. (2014), researches on service quality that affects consumer satisfaction with public transportation have been conducted. There have been some reviews of consumer preferences in choosing public transportation. In addition, there are also several previous literature reviews that discuss aspects of service quality on public transportation. And because mikrotrans is a paratransit type vehicle, several previous studies also discuss the aspects of service quality in paratransit vehicles.

\section{Service Quality}

There are several definitions of service quality. Quality is a dynamic condition that affects products, services, people, processes and the environment that meet or exceed expectations (Tjiptono, 2001). While the definition of service is any action or activity that can be offered by a part to another part, which is basically intangible and does not result in any ownership (Kotler, 2002: 83). So that the definition of service quality can be interpreted as an effort to fulfill the needs and desires of consumers as well as accuracy delivery in balancing consumer expectations (Tjiptono, 2007).

Based on Wikipedia's explanation, from a business administration point of view, service quality is an achievement or accomplishment in customer service. Service quality is all forms of activities carried out by the company in order to meet the hope or expectations of consumers. The amount of service quality can be calculated from the difference between the performance of a service and consumer expectations. Customers, of course, have an expectation of a service they receive so they will be able to assess how much the service quality they have received.

The assessment can come from a comparison between the services they have received and expected before receiving the service. In addition, customers can also assess the service quality based on past experiences, word of mouth, or advertisements. Service quality will be positive if the performance of a service is higher than consumer expectations, and will be negative if the performance of a service is lower than consumer expectations. It can be seen that to vastly increase the service quality, that must be done by increasing the performance of a service so that it will far exceed customer expectations. Therefore producers or service providers must be able to continuously improve the quality of their services to create a good impression in the customer's view.

\section{Consumer Preferences}

In order to increase customer satisfaction, the first thing which is very important is to identify what consumers prefer when they use a product or service. For this, the theory about consumer preferences will be useful. Because we also need to know the characteristics of consumers whom we will make a market target. Consumer preferences will determine the consumer's decision to spend their income on a number of goods and services to obtain maximum satisfaction (utility). In consumer behavior theory, consumer preferences are formulated in a function called the following utility function:

$U=f(X 1, X 2,,,,,,,, X n)$

The consumer will decide how much Xi needs to be purchased to maximize $U$ with given income. In a simple mathematical formula:

$\operatorname{Max} U=f(X 1, X 2,,,,,,,, X n)$

subject to:

$\mathrm{I}=\mathrm{p} 1 \mathrm{X} 1+\mathrm{p} 2 \mathrm{X} 2, \ldots \ldots+\mathrm{pnXn}$

$\mathrm{Xi}$ is the goods consumed, $\mathrm{pi}$ is the price of goods and services, and I is income. If only two kinds of goods are simplified then the utility function can be simplified as follows. For example clothes (X1) and food (X2), then the utility maximization problem above can use indifferent curve analysis and budget line. 
Indifference curve is a curve that shows various combinations of goods that have the same level of satisfaction (utility), while the budget line is a line that shows various combinations of goods whose total expenditure is same as in the following figure:

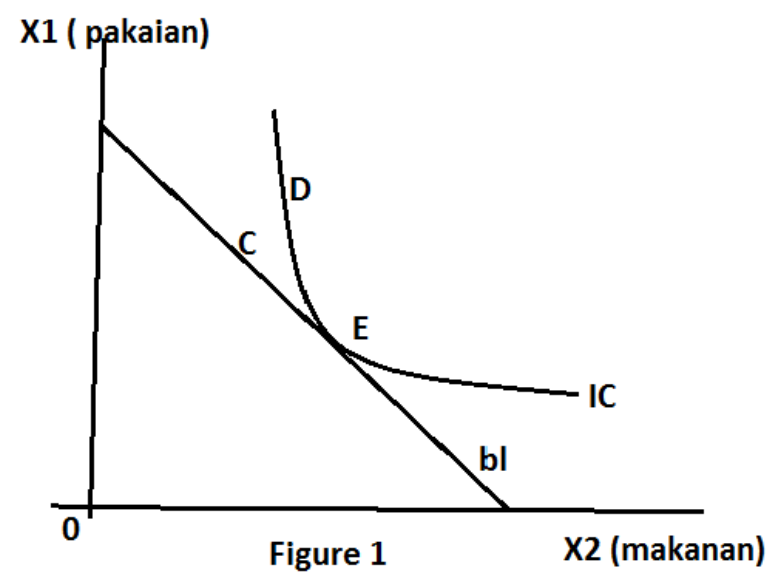

$\mathrm{IC}$ is an indifference curve and $\mathrm{bl}$ is a budget line. Consumers will choose a combination at point $\mathrm{E}$ because with given income, point $E$ provides maximum satisfaction. The combination at point $\mathrm{C}$ is not chosen because the satisfaction level is below IC, while point $D$ is not also chosen even though the satisfaction is same with $C$ but the income is not sufficient. Likewise, in relation to choosing transportation services, a consumer will also face several available public transportation alternatives. Of course they will choose public transportation based on certain considerations. But the most important thing when choosing existing public transportation alternatives, consumers definitely want to use transportation that they feel can provide maximum satisfaction or utility.

As explained above, utility maximization is not always the same when several people choose the same object. This is because the preferences and ability to pay for each consumer can be different. Similar to when choosing a product or service, in choosing public transportation, consumers will also choose a combination at point $E$ in order to get maximum satisfaction depending on their income, namely a combination of service quality and price. If on the curve above $X 1$ is clothes and $X 2$ is food, then in the case of transportation selection $X 1$ is service quality and $\mathrm{X} 2$ is the ticket price. Point $E$ shows the combination of service quality level and ticket price that gives maximum satisfaction with given income. Consumer behavior can be different in determining priorities when choosing public transportation. There are consumers who prioritize the price of the transportation, but some consumers prioritize its convenience. This is the importance of the ability of Transjakarta persons in analyzing and positioning several public transportations in Jakarta, so that mikrotrans can be promoted to the right market segment. The following curves provide various preferences from consumers in choosing the mode of transportation.

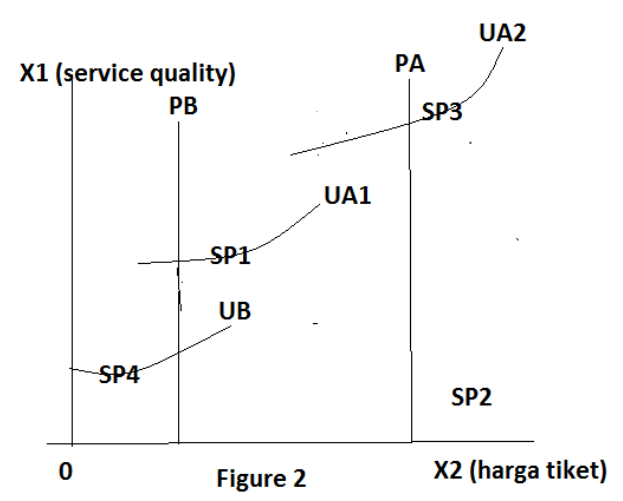

The curve above illustrates four modes of transportation with different combinations. SP1 is a mode of transportation with low ticket prices but high service quality (SQ); SP2 is mode with high price ticket but low SQ; SP4 is mode with low SQ and price, while SP3 is mode with high $\mathrm{SQ}$ and price. Maybe the examples of SP4 are conventional microbus and metromini, SP2 is taxi bike (ojek), SP3 is taxi, and SP1 is mikrotrans. It is also important to note that the shape of the UA indifference curve, which measures a certain preference at a given utility level of consumer $A$, is positive. Its utility shape is positive because the service quality has a direct relationship with ticket prices, which means the higher the service quality will make the higher the ticket price and vice versa. In the example above, which mode of transportation will be chosen by $A$ depends on their ability to pay and their preference which is represented by the UA indifference curve. If their ability to pay is shown by the PA line then they will choose SP1 because it gives the highest satisfaction. Although SP3 provides a higher utility than SP1, it cannot be reached by A. SP2 will not be chosen because it is outside A's range as well as low service quality (SQ). For example, consumer B's ability to pay is shown by the PB line and its preference is shown by UB's indifference curve, then there is no other choice for them expected to choose SP4.

\section{Service Quality in Paratransit}

Faculty of Economics and Business, 


\section{An Analysis of Consumer Behaviors in Choosing Public Transportation (A Case Study at TransJakarta Microbus-Mikrotrans)}

Several previous reviews have tried to observe the service quality of public transportations and want to further investigate the service quality on paratransit vehicles. One of the objectives of this study is to measure how satisfied consumers are with the services provided by paratransit vehicles. Based on references to several previous studies, there are several ways or methods that can be used to improve the service quality of paratransit vehicles. And from several studies, in order to improve the service quality on paratransit vehicles, it is very important to find out first how satisfied consumers who have used public transportation services from paratransit type vehicles. From there the evaluation can be done to make improvements in the future.

As previously explained, the provision of several modes of public transportation in Jakarta, including mikrotrans, aims to make many people want to switch from private vehicles. In line with that, there is also a reference from one of the previous studies that examined factors or variables that can reduce people's dependence on the use of private vehicles. One of them is research from Mageean and Nelson (2003); Enoch et al. (2004); Palmer et al. (2004); Brake and Nelson (2007), which shows if the application of advanced technology installed in public transportation will increase the demand for public transportation services, including the provision of facilities for people with physical disabilities. In contrast, the lack of daily income for drivers and the fares charged to them for vehicle depreciation can be factors which make the poor service quality of paratransit vehicles (Roger Behrensa, Dorothy McCormick, Risper Orero, and Marilyn Ommeh, 2017). Therefore, TransJakarta also wants to provide the best possible facilities that have never existed in conventional public transportation for the passenger's comfort.

However, there is a bad record which must be a serious concern for TransJakarta. Previous research has shown that paratransit vehicles in Asia have a high accident risk. That is because the driver often drives recklessly and does not really care about the feasibility of the vehicles (Veng Kheang Phun, Hironori Kato, and Tetsuo Yai, 2018). Although paratransit vehicles are generally under direct government or private supervision based on certain agreements, still governments in some poor and developing countries are unable to continuously monitor the performance of drivers (Christopher Plano, Roger Behrens, and Mark Zuidgeest, 2020). This is what makes the service quality on paratransit vehicles become worse, especially when the driver can not be directly controlled or supervised by the government. These problems also become the duty of TransJakarta to prevent the factors that can cause accidents as well as the poor service quality at mikrotrans.

Due to the general condition of paratransit vehicles in Asia as mentioned above, this study aims to be able to produce recommendations that can help TransJakarta which is under the control of DKI government to make strategies that can increase service satisfaction on paratransit vehicles, as well as make Mikrotrans passengers feeling safe when riding them. Evaluations are also needed so that mikrotrans can always provide the best service to its passengers. For this reason, this article will make an analysis using linear regression which can be used to assist TransJakarta in determining the right strategy to realize the above objectives. This point will be discussed further in the research methodology chapter.

There is also an analysis of several factors or variables in the service quality of microtrans which have such significant influence on consumer satisfaction which can be used as evaluation by TransJakarta in the future. From the analysis, it can be seen the comparison between the performance that has been done by mikrotrans with consumer expectations of mikrotrans. It can also be seen the quality of mikrotrans services that have been provided to passengers so that in the future TransJakarta can always increase customer satisfaction with mikrotrans services or even improve the existing lack of services.

According to Harifah Mohd Noor, $\mathrm{Na}$ 'asah Nasrudin, and Jurry Foo in 2014, stated that there are 24 variables implemented to measure satisfaction level on public buses, including the microbus. Those 24 parameters are Safe Terminal, Convenience Fare, Cheap Fare, Bus in Good Condition, Near Bus Stop, Efficient Driver, Comfortable Music, Easy Access to Bus Stop, Good Coverage, Easy to Change Buses, Friendly Driver, Bus Schedule Available , AirConditioner, Clean Bus, Bus Info, Waiting Time, Bus on time, Clean Terminal, Facilities in Good Condition, Safe on the Bus, Convenience for elderly / disabled, Easy to Carry Item on Board, Safe at Night, and Not Crowded. The variables above apply to paratransit type vehicles where the microbus is a paratransit type vehicle.

However, the variables contained in the questionnaire are not exactly the same with all variables above since not all variables above are 
available in mikrotrans. And in implementing parasuraman theory, there are 5 parameters consisting of 27 variables as the aspects of service quality theory which determine good service quality. The five parameters are tangible, reliability, responsiveness, assurance, and empathy. Those 27 variables are asked in the questionnaire which belong to 5 parameters of service quality:

Tangible:

- Interior and exterior design of mikrotrans [1]

- Spacious room inside mikrotrans [2]

- Cleanliness inside mikrotrans [3]

- The comfort of mikrotrans seat [4]

- The density of passengers that is often felt inside mikrotrans [5]

- The number of routes or areas passed by mikrotrans until now [6]

- The places where become the bases for mikrotrans [7]

- The places where become mikrotrans passengers drop [8]

- The feasibility of vehicle and the facilities inside it [9]

- Payment method to ride on mikrotrans [19]

Reliability:

- The easiness in reaching places where become the bases for mikrotrans [14]

- Waiting time to get the next mikrotrans when the first one is full [21]

- Waiting time until get on the mikrotrans [15]

- The length of time from getting on a mikrotrams until arriving at the destination [16]

- Safety and comfort that is felt from the driver's driving style [17]

- The price that must be paid to ride the mikrotrans [18]

- The easiness when we want to change from mikrotrans to other modes of transportation [22]

Responsiveness:

- The driver's responsiveness in managing passengers who get on and off [23]

- TransJakarta responsiveness in solving problems often felt by Mikrotrans customers [24]

Assurance:

- TransJakarta knowledge in answering every question from mikrotrans customers [12]

- TransJakarta understanding in seeing the needs and interests of mikrotrans customers [13]

Faculty of Economics and Business,

Brawijaya University
- Certainty to get the mikrotrans which we want to ride [20]

- Security guarantee felt by passengers from crimes when waiting for a mikrotrans [25]

- Security guarantee felt by passengers from crimes while inside the mikrotrans [26]

- Safety guarantee felt by passengers from traffic accidents while inside the mikrotrans [27]

Empathy:

- Politeness and friendliness of the driver [10]

- Attention from TransJakarta crew in responding to complaints from mikrotrans customers [11]

Note: The number at each variable explain the variable in the table which show the result that explain the number of respondents who choose each scale from 27 variables in the result and discussion chapter

\section{RESEARCH METHODOLOGY}

Research uses quantitative methods with linear regression analysis tools method where the validity and reliability test have been conducted in providing an analysis of the factors that become consumer preferences in choosing public transportation and the variables that affect the service quality of mikrotrans. However, before the data is processed, data collection is carried out first. Data collection was carried out by looking for people to be asked about mikrotrans. Prospective respondents were randomly searched in several places and the sampling was done by purposive sampling technique at this stage where people who were asked have certain characteristics to increase the possibility if they are respondents who meet the criteria. The characteristics are the people who were asked were around the base of mikrotrans, even some samples were also questioned inside the mikrotrans where the author also entered the mikrotrans. After finding people who are potential to become respondents, they must be confirmed first if they agreed or not to be asked some questions related to this research. And if they don't, they won't be asked further. And to those who agreed, they must be confirmed whether they are the respondents who met the criteria or not. Respondents who met the criteria are those who have ridden mikrotrans at least once. And only respondents who agreed to be asked and also meet the criteria that will be asked several questions which are sent to their email in the form of a questionnaire. 
However, due to the Covid-19 disaster that spread to the world including Indonesia, random seek for potential respondents in several places could no longer be done when the amount of data had not met the minimum number, due to various regulations that made it impossible to find people directly. Therefore, as a solution for further data collection, the search for potential respondents was carried out from friends and relatives' references, and the author himself also asked several friends, relatives, and acquaintances with WhatsApp media to confirm whether they agreed to be asked related to this research and including respondents who meet the criteria or not. So in this step, the sampling method was changed to probability sampling. And the next steps are the same as before.

The data were collected between February 2020 until August 2020. During data collection process, the respondents were sorted first whether they met the criteria or not because some respondents who were obtained from references did not meet the criteria. The respondents who met the criteria were sent the questionnaire to their respective email. After the questionnaire containing the questions in this study had been sent to all respondents who met the criteria, they were asked to answer all the questions on the questionnaire based on their personal experience in using mikrotrans. The question asked to the respondents regarding the scale of their satisfaction level with the 27 variables. Respondents were asked to rate each variable in the question based on their respective satisfaction. The answers given by respondents are in the form of a Likert Scale with a scale of 1-4 where 1 is very dissatisfied, 2 is dissatisfied, 3 is satisfied, and 4 is very satisfied.

This is the model of linier regresion:

Model Summary
\begin{tabular}{|l|c|r|r|r|}
\hline Model & $\mathrm{R}$ & R Square & $\begin{array}{c}\text { Adjusted } \\
\text { R Square }\end{array}$ & $\begin{array}{r}\text { Std. Error of } \\
\text { the Estimate }\end{array}$ \\
\hline 1 &, $864^{\mathrm{a}}$ &, 746 &, 738 &, 27809 \\
\hline
\end{tabular}
a. Predictors: (Constant), EMPATHY, RELIABILITY,
RESPONSIVENESS, TANGIBLE, ASSURAMNCE

There are 5 variables which are used to in the model to measure service quality of mikrotrans which are: Empathy, reliability, responsiveness, tangible, dan assurance. Those 5 variables are abbreviation from 27 variables who were asked to the respondents, because several variables are merged into $1 \mathrm{up}$ to a total of 5 .

After all questions in the questionnaire have been answered, then the data is processed.

Faculty of Economics and Business,

Brawijaya University
Data processing was carried out using linear regression method using SPSS software. There are 169 respondents who have answered the questionnaire in this study. Before the data was processed with SPSS, the total satisfaction scores of all variables for each respondent had been calculated first. Because there are 27 variables where each variable is scored on a scale of 1-4, the lowest possible total score is 27 and the highest is 108. The satisfaction is classified into 4 types of satisfaction scales with certain interval lengths. Total scale of 27-46 shows a very low level of satisfaction and is given a score of 1 , total scale of $47-67$ shows a low level of satisfaction and is given a score of 2 , total scale of $68-88$ shows a high level of satisfaction and is given a score of 3 , and total scale of 89-108 shows a very high level of satisfaction and is given a score of 4 .

\section{RESULTS AND DISCUSSION}

After all respondents had answered the questions on the questionnaire and the data had been processed, the results showed that the variables in the mikrotrans were classified as good in general.

Referring to Table 1, the results of estimation are as follow:

SAT $=$ -

$0,528+0,54 \mathrm{TAN}+0,248 \mathrm{REL}+0,086 \mathrm{RES}+0,231 \mathrm{~A}$ SS+0,108EMP

where

SAT $=$ Consumer satisfaction

TAN = Tangible that is physical appearance

$\mathrm{REL}=$ Reliability

RES $=$ Responsivenss

ASS $=$ Assurance

$\mathrm{EMP}=$ Empathy

Simultaneous test in Table 2 indicate that 74.6 percent of consumer satisfaction can be explained by the model $\left(R^{2}=0.746\right)$ while partial test in Table 1 show that tangible, reliability, and assurance are strongly determine consumer satisfaction (t-value are 5.869, 2.626, and 2.596 respectively) while responsiveness and empathy are less determine consumer satisfaction (t-value 1.224 and 1.634 respectively). 


\begin{tabular}{|c|c|c|c|}
\hline \multirow[b]{2}{*}{ Model } & & \multicolumn{2}{|c|}{$\begin{array}{l}\text { Unstandardized } \\
\text { Coefficients }\end{array}$} \\
\hline & & B & $\begin{array}{l}\text { Std. } \\
\text { Error }\end{array}$ \\
\hline \multirow[t]{5}{*}{1} & $\begin{array}{l}\text { (Constant) } \\
\text { TANGIBLE }\end{array}$ & $\begin{array}{r}-, 528 \\
, 540\end{array}$ & $\begin{array}{l}, 168 \\
, 092\end{array}$ \\
\hline & $\begin{array}{l}\text { RELIABILI } \\
\text { TY }\end{array}$ & 248, & ,095 \\
\hline & $\begin{array}{l}\text { RESPONSI } \\
\text { VENESS }\end{array}$ & ,086 & ,070 \\
\hline & $\begin{array}{l}\text { ASSURAM } \\
\text { NCE }\end{array}$ & ,231 & ,089 \\
\hline & EMPATHY & ,108 & ,066 \\
\hline
\end{tabular}

Table 1

Standafelpendent variable, while each of 5 pakameters whose average yalue is used as Codifferearesdent variables.

Betgxplained in the ressigrch and methodology

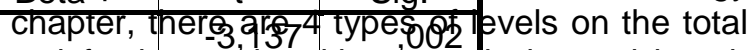

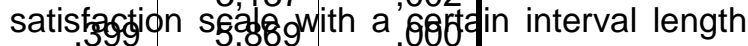
where the $27-46$ scale shows a very low level of satisfleteion äafizgiven abeore of 1 , a scale 4767 shows a low level of satisfaction and is given

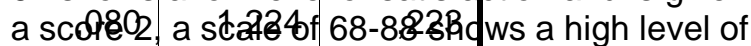
satisfaction and is given a score of 3 , and a scale of 892088 sho $2{ }^{8} 96$ very high 9 evel of satisfaction and is given ${ }_{16}{ }_{6} 5$ gare of $1_{10}$ then the data is processed, the total satistaction of each respondent is classified first to one of the levels from 1-4 using linear regression.

Model Summary

From the results above, it can be concluded that the tangible, reliability, and assurance

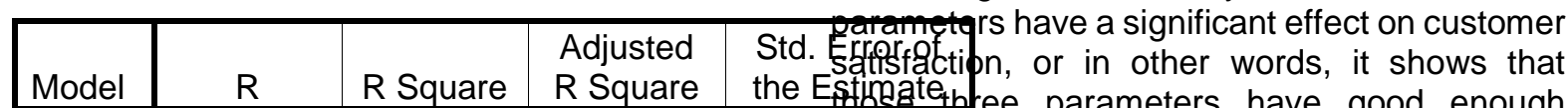
,738

a Predictors: (Constant), EMPATHY, RELIABILITY, RESPONSIVENESS, TANGIBLE, ASSURAMNCE

Table 2

These 27 variables are classified into 5 parameters as described above based on the Parasuraman Theory. Because each of the 5 parameters has a different number of variables, the total satisfaction scale of all variables in each parameter (where each variable has been rated on a scale of 1-4) is to be averaged first. Then for the assessment of the total satisfaction of each respondent obtained from the sum of the total scale of the 27 variables. This is the table of result that shows the number of respondents who choose each scale from 27 variables:

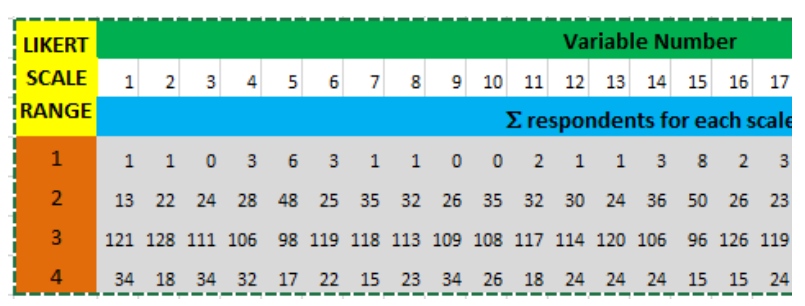

Note: The detail of each variable which is represented by number can be seen in the part Service Quality in Paratransit

As explained above, the total of 27 variables were summarized and merge into only 5 variables which become parameters to measure service quality. The total satisfaction is used as

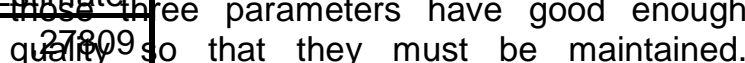
Meanwhile, the responsiveness and empathy parameters do not have a significant effect, so the quality of the two parameters must be improved because they have not sufficiently satisfied consumers.

To find out which variable of the parameter has the highest and the lowest satisfaction level is done by summing up the individual scores of each respondent. And from the range of scores of 169 to 676 , from the 3 parameters that have a strong influence on customer satisfaction, the variable with the highest score on tangible parameter is mikrotrans payment method with a score of 538 , the highest variable in reliability parameter is the price of mikrotrans with a score of 550, and the highest on the assurance parameter is Trans Jakarta's understanding in seeing the needs and interests of Mikrotrans customers with a score of 505 .

As for the two parameters which are not really influential in determining customer satisfaction, in the responsiveness parameter, Trans Jakarta's responsiveness in overcoming problems that are often experienced by mikrotrans customers has the lowest score with a score of 491 , while on the empathy parameter, the attention of the Trans Jakarta persons in responding complaints from customers of mikrotrans which has the lowest score with a score of 489.

Faculty of Economics and Business,

Brawijaya University 


\section{An Analysis of Consumer Behaviors in Choosing Public Transportation (A Case Study at TransJakarta Microbus-Mikrotrans)}

Because this model can only explain customer satisfaction by 74.6 percent, $25.4 \%$ is influenced by other factors outside of this model.

\section{CONCLUSION}

The results of model estimation show that consumer satisfaction is determined by all 5 parameters although they are different in significance. These findings are in line with the Theory of Service Quality by Parasuraman. Further calculation of variable scores of the 3 parameters which have strong effect on consumer satisfaction for tangible parameters, method of payment has the highest score; for reliability parameter, price has the highest score, for assurance parameter, the understanding of Mikrotrans on consumer preference has the highest score. Calculation of variable scores of the 2 parameters which have less effect on consumer satisfaction for responsiveness parameter, response of $\mathrm{TJ}$ to consumer problems has the lowest score and for empathy parameter, response of $\mathrm{TJ}$ to consumer complaints has the lowest score. It implies that the quality of tangible, reliability, and assurance, should be kept on by $\mathrm{TJ}$, while the quality responsiveness and empathy should be improved.

For further research, the variables in this journal can be used for those want to examine the service quality on a paratransit type vehicles, but the variables used may not exactly be the same as used in this research. Since the researched object in this journal is mikrotrans, so it must be determined in the next research what variables are most appropriate to be used which must be adjusted to the type of researched vehicle object. One more thing that might be suggested for further research, since this research is just a case study at Mikrotrans $\mathrm{TJ}$, it is recommended for further research to cover other public paratransit type vehicles so that the findings will be more comprehensive.

\section{REFERENCES}

Pindyck, Robert S and Rubinfeld, Daniel L, Microeconomics, fifth edition, 2001

Berry, L. L., Parasuraman, A., \& Zeithaml, V. A. (1994). Improving service quality in America: Lessons learned. Academy of Management Perspectives, 8(2), 32-45. https://doi.org/10.5465/ame.1994.9503101 $\underline{072}$

Giannakis, M., \& Bullivant, N. (2016). The massification of higher education in the UK: Aspects of service quality. Journal of Further and Higher Education, 40(5), 630648.

https://doi.org/10.1080/0309877X.2014.10 $\underline{00280}$

Of, T. H. E. C. (2007). A model for quality assessment in higher education: implications for ODL universities. Malaysian Journal of Distance Education, 9(2), 125-143.

Rajaei, Z. (2018). Measurement of Service Quality and its Relationship with the Client 's Satisfaction Through SERVQUAL Model in the Gas Company Measurement of Service Quality and its Relationship with the Client's Satisfaction Through SERVQUAL Model in the Gas Company. January 2012. https://doi.org/10.5829/idosi.mejsr.2012.1 $\underline{2.8 .503}$

Pakurár, M., Haddad, H., Nagy, J., Popp, J., \& Oláh, J. (2019). The service quality dimensions that affect customer satisfaction in the Jordanian banking sector. Sustainability (Switzerland), 11(4), 1-24. https://doi.org/10.3390/su11041113

Hermiyanty, Wandira Ayu Bertin, D. S. (2017). Pengaruh Brand Image, Kualitas Produk, Dan Reference Group Terhadap Minat Beli Produk Kosmetik Lipstik Wardah DI Kota Malang. Journal of Chemical Information and Modeling, 8(9), 1-58.

Service Quality. (n.d.). In Wikipedia. Retrieved 14 July 2020 from https://en.wikipedia.org/wiki/Service qualit y

Linear Regresion. (n.d.). In Wikipedia. Retrieved 7 April 2021 from https://en.wikipedia.org/wiki/Linear regres sion

M Kobiruzzaman, M. 2020. 5 Dimensions of Service Quality - Servqual Model of Service Quality. Retrieved from https://newsmoor.com/servqual-modelfive-key-service-dimensions-servqualgaps-reasons 
Nugroho, S. B., \& Zusman, E. (2018). Low carbon paratransit in Jakarta, Indonesia: Using econometric models to improve the enabling environment. Case Studies on Transport Policy, 6(3), 342-347. https://doi.org/10.1016/i.cstp.2018.03.006

Sharma, D., Pandit, D., \& Bose, T. (2020). Determination of service quality attributes based on user perception for paratransit services in developing country like India. Transportation Research Procedia, 48(2019), 3577-3594. https://doi.org/10.1016/j.trpro.2020.08.093

Wongwiriya, P., Nakamura, F., Tanaka, S., Ariyoshi, R., \& Miura, S. (2020). The Role of Paratransit to Support Sustainable Transportation: Case Study of Khon Kaen City, Thailand. Transportation Research Procedia, 48(2019), 2656-2670. https://doi.org/10.1016/j.trpro.2020.08.247

Dikas, G., \& Minis, I. (2014). Scheduled paratransit transport systems. Transportation Research Part B: Methodological, 67, 18-34. https://doi.org/10.1016/j.trb.2014.05.001

Tiglao, N. C. C., De Veyra, J. M., Tolentino, N. J. Y., \& Tacderas, M. A. Y. (2020). The perception of service quality among paratransit users in Metro Manila using structural equations modelling (SEM) approach. Research in Transportation Economics, 83(November 2019), 100955. https://doi.org/10.1016/j.retrec.2020.10095 $\underline{5}$

Influence, T., Service, O., On, P., Interest, C., \& Brand, P. (2020). ICoMS2020. 1(1), 161167.

Behrens, R., McCormick, D., Orero, R., \& Ommeh, M. (2017). Improving paratransit service: Lessons from inter-city matatu cooperatives in Kenya. Transport Policy, 53(September 2016), 79-88. https://doi.org/10.1016/j.tranpol.2016.09.0 $\underline{03}$

Phun, V. K., Kato, H., \& Yai, T. (2018). Traffic risk perception and behavioral intentions of paratransit users in Phnom Penh. Transportation Research Part F: Traffic Psychology and Behaviour, 55(April), 175-187. https://doi.org/10.1016/.j.trf.2018.03.008
Noor, H. M., Nasrudin, N., \& Foo, J. (2014). Determinants of Customer Satisfaction of Service Quality: City Bus Service in Kota Kinabalu, Malaysia. Procedia - Social and Behavioral Sciences, 153(October), 595605.

https://doi.org/10.1016/j.sbspro.2014.10.0 $\underline{92}$ 